Saudi Journal of Business and Management Studies Abbreviated Key Title: Saudi J Bus Manag Stud ISSN 2415-6663 (Print) |ISSN 2415-6671 (Online) Scholars Middle East Publishers, Dubai, United Arab Emirates Journal homepage: https://saudijournals.com/sjbms

Original Research Article

\title{
Identifying Issues and Measuring Financial Risks: A Case Study of Public Sector Banks in India
}

\author{
Kishore Meghani"
}

Research Scholar M.B.A. Finance, M.A. Economics., M.Com. Accounts \& Law, CBSE-UGC-NET (Commerce) NSE

Academy Certified Market Professional (NCMP) - Level 1 Ex-Branch Head, The Nainital Bank Ltd.

DOI: $10.36348 /$ sjbms.2020.v05i07.004

| Received: 23.06.2020 | Accepted: 01.07.2020 | Published: 08.07.2020

*Corresponding author: Kishore Meghani

\section{Abstract}

The Prime objective of the study was to find out the certain financial and operating issues prevailing in the Public sector banks in India. Issues which are identified in the research study includes:(i) Rise in cyber-attacks,(ii) Money Laundering cases,(iii) Non-Performing Assets of public sector banks,(iv) Inability to implement Basel III due to weak capital position, and (v) Challenges in Financial Inclusion along with low profitability of public sector banks about their massive asset base. The research paper also measures the volatility, systematic risk and unsystematic risk associated with 12 banks that are constituents of the S\&P NSE banking index (BANKEX) (Nifty Bank INDEXNSE: BANKNIFTY) based on their daily returns. The Research study is to identify financial and operating risks prevalent in the Public Sector Bank. Parameters such as volatility and total risk change with respect to time, vary with bank, and thus need to be measured to enable better investing decisions. The study measures these parameters for stocks included in the S\&P NSE's banking index (BANKEX) (Nifty Bank INDEXNSE: BANKNIFTY). For volatility, the paper calculates the beta value of stocks with reference to the market index (S\&P NSE Nifty). While calculating the value of beta acts as an input for further measuring value of systematic as well as unsystematic risk.

Keywords: NSE-National Stock Exchange, Nifty Banking, Beta, Issues, Risk, Systematic Risk, Unsystematic Risk, Volatility.

Copyright @ 2020: This is an open-access article distributed under the terms of the Creative Commons Attribution license which permits unrestricted use, distribution, and reproduction in any medium for non-commercial use (NonCommercial, or CC-BY-NC) provided the original author and source are credited.

\section{INTRODUCTION}

As soon the bottom lines of Domestic Banks come under increasing pressure and the options for organic growth exhaust themselves, Indian Banks will need to explore ways for inorganic expansion. This, in turn, is likely to unleash the forces of consolidation in Indian banking.

\section{-Dr. Chakravarthi Rangarajan Sir}

$19^{\text {th }}$ Governor of the Reserve Bank of India Former Chairman of Economic Advisory Council of the Prime Minister

\section{What is risk?}

Risk is an important consideration in holding any portfolio. The risk in holding securities is generally associated with the possibility that realised returns will be less than the returns expected.

"Risks are usually defined by the adverse impact on profitability of several distinct sources of uncertainty. While the types and degree of risks and organization may be exposed to depend upon a number of factors such as its size, complexity business activities, volume etc" [1]. Risk can be classified into systematic and unsystematic risk [2]. Systematic risks are risks associated with the economic, political, sociological and other macro-level changes. They affect the entire market as a whole and cannot be controlled or eliminated merely by diversifying one's portfolio. (National Stock Exchange) [19] .Whereas, unsystematic 
risk is risks that are unique to a firm or industry. Factors such as management capability, consumer preferences, labour, etc. contribute to unsystematic risks. Unsystematic risks are controllable by nature and can be considerably reduced by sufficiently diversifying one's portfolio. (National Stock Exchange) [19]. It is also known as specific risk, residual risk or diversifiable risk.

\section{What is Beta?}

The degree, to which different portfolios are affected by these systematic risks as compared to the effect on the market as a whole, is different and is measured by Beta. To put it differently, the systematic risks of various securities differ due to their relationships with the market. The Beta factor describes the movement in a stock's or a portfolio's returns in relation to that of the market return. For all practical purposes, the market returns are measured by the returns on the index (Nifty, Mid-cap etc.), since the index is a good reflector of the market (National Stock Exchange) [19].

Indian banking industry has witnessed major structural changes post liberalisation including decontrol of interest rates, privatisation, direct credit, etc. The implications of these reforms have created several financial and operating issues such as rising NPAs, weak capital position, increasing number of frauds, and slow pace of financial inclusion along with others.

The modern banking industry has stronger regulations and gradual reduction in administrative activities as well as absolute values of interest rates. For instance, requirements for cash reserve ratio reduced from $15 \%$ in 1991 to $4 \%$ in 2019 and similarly the statutory liquidity ratio also decreased from $38.5 \%$ in 1991 to $19.25 \%$ in 2019.

\section{REVIEW OF LITERATURE}

Bhide et al. [3] through their study found that these structural changes resulted in increased competition, reckless lending, gap between capital requirements, and availability to raise the funds, recapitalisation of banks, and increasing nonperforming assets.

Kamath et al. [4], they identified that lack of operational efficiency of Indian banks was another setback which resulted in problem of low profitability and increasing non-performing assets.

Ranjan \& Dhal [1], the reasons for increasing non-performing assets were identified. They stated that changes in cost of credit in expectation of higher interest rate is one of the reasons for increasing nonperforming assets of banks.

Mohan [5], who found that a considerable stock of non-performing assets, increasing savings, and interest rates are a major concern for Indian financial system. Thus, low operational efficiency, weak capital position, and increasing non-performing assets remained a major concern for Indian banking industry.

Dev [6], in his study stated that financial inclusion plays a significant role and banking institutions should look at financial inclusions as a business opportunity.

Mohan [7], in his study discussed that despite financial deepening, breadth and coverage of formal finance is still inadequate. He further claimed that for entrepreneur, assessment, and management of risk at low cost, and simplification of delivery process in banks' outreach to untapped markets are the issues which should be given priority for sound financial inclusion.

Golait [8], Raman [9], Ghosh [10], and Goyal \& Joshi [11, 12], stressed that for sound financial inclusion and to reduce the stock of non-performing assets, it was necessary for banks to focus upon innovative banking practices, train and develop human resource, and achieve operational efficiency.

Singh et al. [13], highlighted that despite the efforts of banking institutions, $90 \%$ of the rural household remained deprived of banking services. The reason for such deprivation remains lack of financial literacy. Thus, financial inclusion is low due to operational inefficiency of banks.

Singh et al. [14], further contributed and identified that the underlying reasons for frauds included lack of proper supervision of top management, conspiracy between the staff, corporate borrowers \& third party agencies, fragile regulatory framework, lack of appropriate equipment and technologies in banks to sense early warning signals of a scam, and lack of synchronisation among different banks including both the local as well as foreign banks.

Lakshmi [15], attempted to measure and compare the volatility of sector-related indices in Indian stock market. The author found that banking sector had the lowest volatility in contrast to realty sector for the test period (2008-2011).

Rajmohan et al. [17], further measured the influence of banking sector on other sectors using correlation analysis in both bear phase (January 2008 to October 2008) and bull phase (November 2008 to December 2013). They concluded that there existed a positive correlation between banking index and other indices in both phases.

William et al. [17], examined the volatility of five select private by using mean, standard deviation, and beta values. They concluded that the measured value of volatility was similar for all the five banks. 
Shukrant Jagotra [18], attempted to identifying Financial \& Operating Issues and Measuring Systematic \& Unsystematic Risks (A Study of Indian Banking Sector) i.e.Private Sector Banks and Public Sector Banks

\section{OBJECTIVES OF THE STUDY}

- To identify financial and operational issues in the Public Sector Banks in India through secondary qualitative research.

- To measure the $\beta$-coefficient of all constituents stocks of S\&P NSE BANKEX Index (Nifty Bank INDEXNSE: BANKNIFTY)

- To calculate the variance, systematic \& unsystematic risk, and co-efficient of determination associated with the constituents stocks of S\&P NSE BANKEX Index (Nifty Bank INDEXNSE: BANKNIFTY)

\section{RESEARCH METHODOLOGY}

- Twelve banks listed on the National Stock Exchange and also part of the S\&P NSE
BANKEX (Nifty Bank INDEXNSE: BANKNIFTY) have been selected.

- Data for daily stock returns have been collected for five years, i.e., from April 01, 2014 to March 31, 2019 for the purpose of calculation and analysis.

- The study uses secondary data of daily/weekly closing share prices for shares of selected companies from the website of National stock exchange.

- The study considered daily closing prices of S\&P NSE BANKEX's (Nifty Bank INDEXNSE: BANKNIFTY) constituent stocks as well as daily closing value of S\&P NSE Nifty for a period of five years (April 01, 2014 to March 31, 2019). After calculating daily returns for each of the 12 stocks as well as S\&P NSE Nifty (Nifty Bank INDEXNSE: BANKNIFTY), the study calculated several parameters such as beta, total risk, systematic risk, unsystematic risk, and coefficient of determination using the formula as mentioned in the Table 2 below.

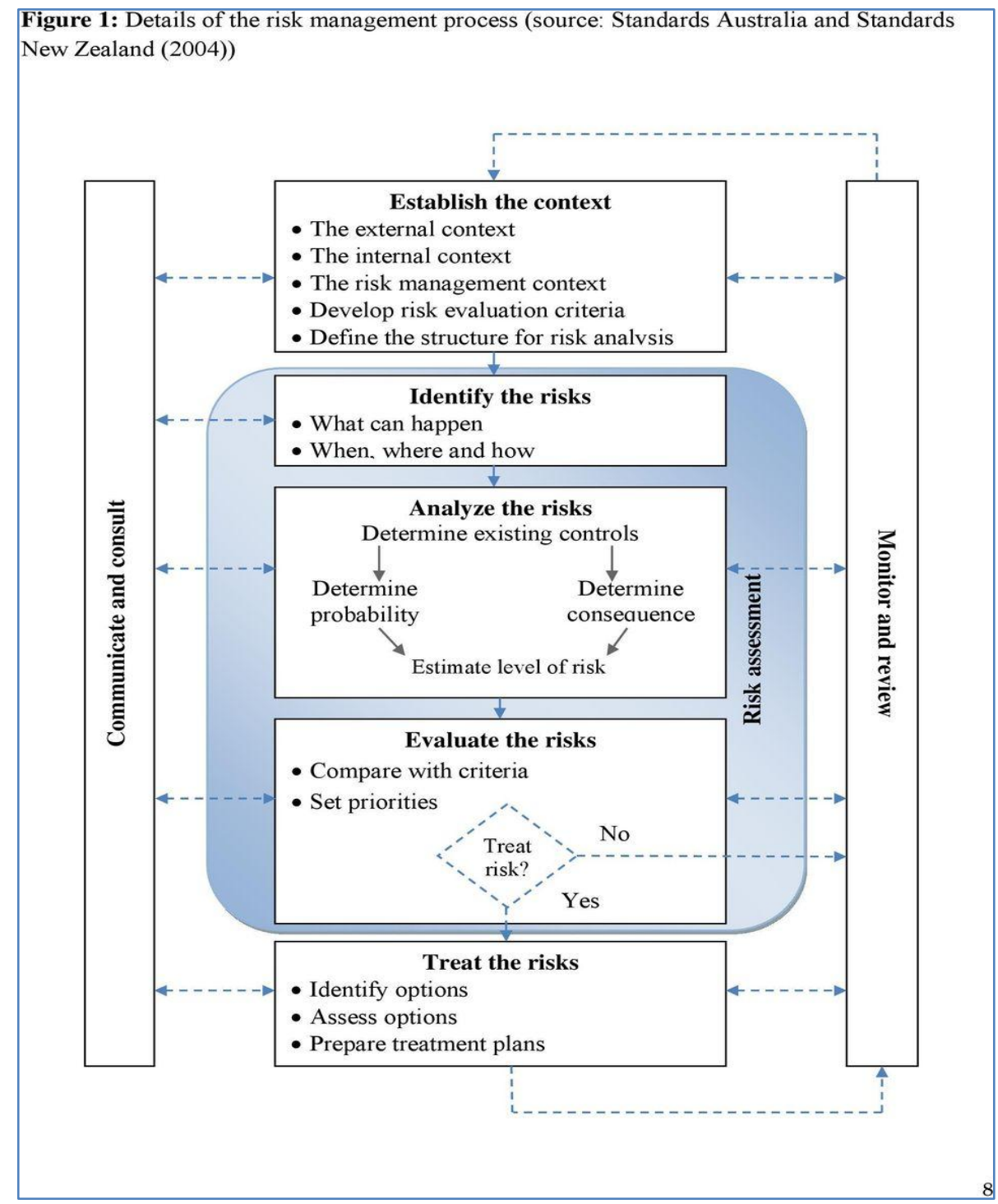


Table-1: Companies Selected for Estimation of Risks

\begin{tabular}{|l|l|}
\hline Sr. No. & Name of the Public Sector Bank \\
\hline $\mathbf{1}$ & Punjab National Bank \\
\hline $\mathbf{2}$ & Bank of Baroda \\
\hline $\mathbf{3}$ & Canra Bank \\
\hline $\mathbf{4}$ & Oriental Bank of Commerce \\
\hline $\mathbf{5}$ & Punjab \& Sind Bank \\
\hline $\mathbf{6}$ & Allahabad Bank \\
\hline $\mathbf{7}$ & Bank of Maharashtra \\
\hline $\mathbf{8}$ & Andhra Bank \\
\hline $\mathbf{9}$ & Corporation Bank \\
\hline $\mathbf{1 0}$ & Union Bank of India \\
\hline $\mathbf{1 1}$ & Syndicate Bank \\
\hline $\mathbf{1 2}$ & United Bank of India \\
\hline
\end{tabular}

Table-2: Parameters and Formulae

\begin{tabular}{|c|c|}
\hline $\begin{array}{l}\text { Daily stock or } \\
\text { Nifty returns }\end{array}$ & $\left(\mathbf{P}_{\mathbf{i}+1}-\mathbf{P}_{\mathbf{i}}\right)^{* 100 / \mathbf{P}_{\mathbf{i}}}$ \\
\hline Beta-coefficient & $\left(\mathrm{n} \sum \mathrm{xy}-\sum \mathrm{x} \sum \mathrm{y}\right) / \mathrm{n} \sum \mathrm{x}^{2}-\left(\sum \mathrm{x}\right)^{2}$ \\
\hline Variance & $(1 / N) \sum\left(x_{i}-\mu\right)^{2}$ \\
\hline Systematic Risk & $\beta_{i}^{2 *} \sigma^{2}$ \\
\hline Unsystematic Risk & $\sigma_{i}^{2}-\beta_{i}^{2 *} \sigma^{2}$ \\
\hline $\begin{array}{l}\text { Coefficient of } \\
\text { determination }\end{array}$ & $\begin{array}{l}\left(\mathrm{n} \sum x y-\sum x \sum y\right) / \sqrt{\left(n \sum x-\left(\sum x\right)\right)} \\
\left(n \sum y^{2}-\left(\sum y\right)^{2}\right)\end{array}$ \\
\hline
\end{tabular}

Where,

$$
\begin{aligned}
& P_{i+1}=\text { price of stock or value of S\&P NSE Nifty on }(i+1)^{\text {th }} \text { day } \\
& P_{i}=\text { price of stock or value of S\&P NSE Nifty on } i^{\text {th }} \text { day } \\
& n=\text { number of observations } \\
& x=\text { daily returns of S\&P NSE Nifty } \\
& y=\text { daily returns of S\&P NSE BANKEX's constituent stocks } \\
& \sigma=\text { variance } \\
& \mu=\text { mean of all observations } \\
& \beta_{i}=\text { beta factor of a particular } i^{\text {th }} \text { stock }
\end{aligned}
$$

Table-3: Beta Factor, Coefficient of Determination (CoD), Systematic Risk, Unsystematic Risk and Total Risk of S\&P NSE BANKEX Constituents (Nifty Bank INDEXNSE: BANKNIFTY)

\begin{tabular}{|l|c|c|c|l|l|}
\hline Name of the Public Sector Bank & Beta & CoD & Systematic Risk & Unsystematic Risk & Total Risk \\
\hline Punjab National Bank & 1.16 & 0.33 & $0.02 \%$ & $0.03 \%$ & $0.05 \%$ \\
\hline Bank of Baroda & 1.72 & 0.23 & $0.02 \%$ & $0.05 \%$ & $0.07 \%$ \\
\hline Canra Bank & 1.69 & 0.38 & $0.01 \%$ & $0.03 \%$ & $0.04 \%$ \\
\hline Oriental Bank of Commerce & 1.31 & 0.19 & $0.02 \%$ & $0.09 \%$ & $0.11 \%$ \\
\hline Punjab \& Sind Bank & 1.18 & 0.32 & $0.01 \%$ & $0.05 \%$ & $0.06 \%$ \\
\hline Allahabad Bank & 1.59 & 0.30 & $0.02 \%$ & $0.08 \%$ & $0.10 \%$ \\
\hline Bank of Maharashtra & 0.91 & 0.28 & $0.02 \%$ & $0.04 \%$ & $0.06 \%$ \\
\hline Andhra Bank & 1.28 & 0.21 & $0.01 \%$ & $0.11 \%$ & $0.12 \%$ \\
\hline Corporation Bank & 1.55 & 0.27 & $0.02 \%$ & $0.10 \%$ & $0.12 \%$ \\
\hline Union Bank of India & 1.68 & 0.25 & $0.01 \%$ & $0.09 \%$ & $0.10 \%$ \\
\hline Syndicate Bank & 1.13 & 0.24 & $0.01 \%$ & $0.08 \%$ & $0.09 \%$ \\
\hline United Bank of India & 1.67 & 0.31 & $0.02 \%$ & $0.09 \%$ & $0.11 \%$ \\
\hline
\end{tabular}

\section{FINDINGS AND OBSERVATIONS}

\section{As per the study's first objective: Identification of} Financial and Operating Issues

Low Profitability vis-a-vis Asset Base of Public Sector Banks - Public banks continues to account for more than $70 \%$ of the total banking sector assets. To increase efficiency as well as reduce interference, the Reserve Bank of India has called for several public sector reforms including the dilution of government's stake to below $50 \%$ in order to increase the asset quality and reduce non-performing assets leading towards increased profitability of public sector banks.

Rising Non-Performing Assets of Public Banks Higher NPAs mean higher provisions on the part of banks. Provisions rose to a level where banks, especially PSBs, started making losses. Recently in
2017, the central bank introduced the preventive corrective action (PCA) framework to reduce NPAs. Under the framework, the RBI has listed three risk thresholds on the basis of capital to risk weighted assets ratio (CRAR), common equity tier-1 ratio and net-NPA ratio along with others. Based on the level of risk threshold, the RBI shall impose restrictions on several banking operation such as dividend distribution, branch expansion, compensation of management, and director's fees. This shall enable the banks to take corrective measures on time enabling them to reduce NPAs.

Weak Capital Position for Complying Basel III Framework - Since April 2013, the RBI has been implementing global capital to risk norms (under which banks shall have to maintain a minimum common equity and total capital ratio of $8 \%$ and $11.5 \%$, 
respectively) which are to be fully implemented by March 2019. Even though most of the public sector banks meet the current statutory norms for CRAR, further improvements are required as the industry migrates to advanced Basel III framework.

However, owing to poor health of some of the public sector banks including Bank of Maharashtra, which have already been put under PCA, the government is in negotiation with the RBI to defer the full implementation of Basel III framework.

Increasing Money Laundering Activities Several urban cooperative banks and public sector banks were scanned by the RBI for violation of anti-money laundering laws and penalised for violation of KYC and anti-money laundering norms; the issue concerning money laundering accentuated after the government announced its decision to demonetise currency of INR500 and INR1000 denomination in November 2016.

Challenges in Financial Inclusion - From the 1960s, the government has taken several initiatives such as nationalisation of banks, setting up regional rural banks, self-help group (SHG), bank linkage programme, and priority sector lending requirements along with others to facilitate financial inclusion in the country.

While the government has been putting continued efforts by launching new schemes such as Prime Minister's Jan Dhan Accounts, stress needs to be laid out in ensuring the opened accounts remain operational.For achieving this, strong government support, extending the role of business correspondents, greater role of technology, and leveraging Aadhaar card details for complying with KYC norms can play a key role.

Rise in Cyber Attacks - With steps such as digital India, digital locker, BHIM app (mobile application for digital payments), and demonetisation, the Indian government is working hard to transition the Indian economy into a digital economy. However, with rising digitalisation, technological risks have also risen significantly.

The Table 3 above measures the beta-coefficient, systematic \& unsystematic risk and co-efficient of determination as per the study's second and third objective

Values of beta factor of constituents stocks of BANKEX with reference to the market index (Nifty) range from 0.91 to 1.72 . Almost all stocks (except Bank of Maharashtra) are more volatile than the overall market (beta factor of overall market is taken as 1). Stock of Bank of Baroda is the most volatile among the group with highest beta factor value of 1.72 followed by Canra Bank (1.69) and Union Bank of India (1.68). On the other hand, Bank of Maharashtra is the least volatile and mimics the market volatility with beta factor value of 0.91 followed by Syndicate Bank (1.13) and Punjab National Bank (1.16).

Coefficient of determination, which depicts the percentage of market variance explained by a particular stock, ranges from 0.19 to 0.38 . Among the stocks under consideration, coefficient of determination is the highest for Canra Bank at 0.38 followed by Punjab National Bank (0.33). The coefficient value is the least for oriental Bank of Commerce at 0.19 followed by Andhra Bank (0.21).

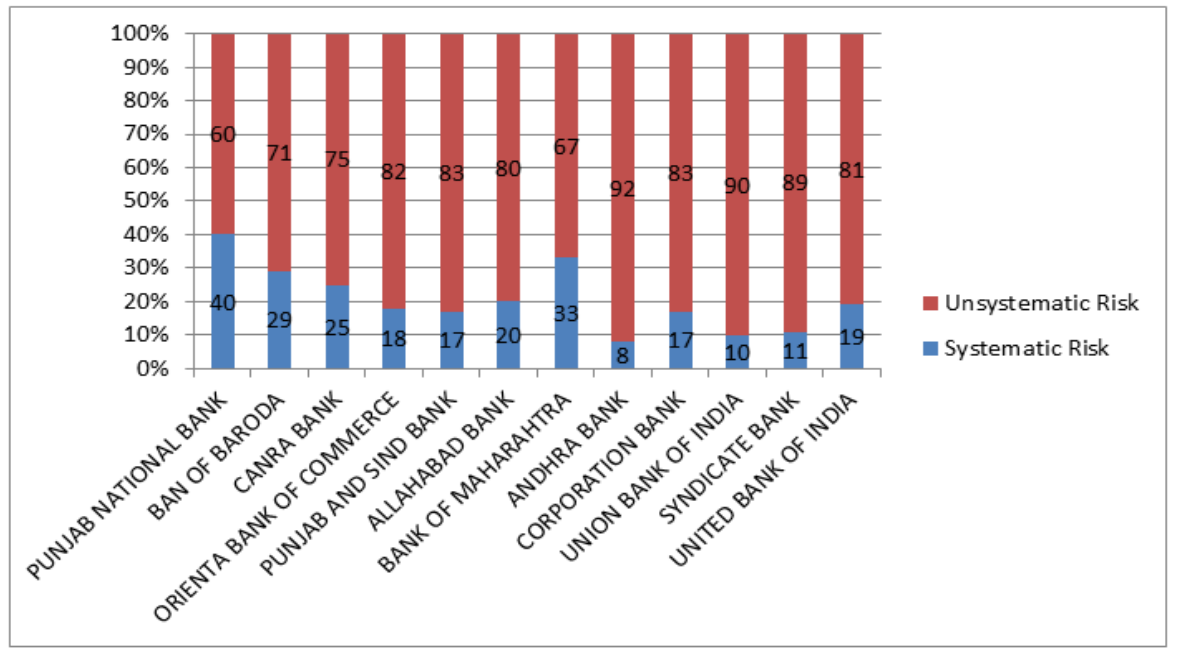

Fig-1: Systematic and Unsystematic Risk as a Percentage of Total Risk

* Systematic Risk as a \% of Total Risk

* Unsystematic Risk as a \% of Total Risk

As shown in Table 3 and Figure 1, total risk is the highest for Andhra Bank and Corporation Bank at
$0.12 \%$ (the value corresponds to variance in daily stock price returns) followed by Oriental Bank of Commerce and United Bank of India at $0.11 \%$. The total risk is the least for Canra Bank at $0.04 \%$ followed by Punjab National Bank $0.05 \%$. Stocks of almost all banks have a 
greater proportion of unsystematic risk than systematic risk. Stocks such as Andhra Bank and Union Bank of India have a greater proportion of unsystematic risk $(92 \%$ \& $90 \%$ of total risk as unsystematic risk) than systematic risk.

\section{CONCLUSION AND IMPLICATIONS}

It identified several issues prevalent in the modern banking industry such as high operating costs \& NPAs of public sector banks, rising cases of moneylaundering \& cyber-attacks, low profitability of public sector banks compared to their asset base along with distant dream of financial inclusion. The study also measured the volatility and systematic \& unsystematic risks associated with S\&P NSE BANKEX (Nifty Bank INDEXNSE: BANKNIFTY) constituent stocks. Stocks of almost all banks had a beta factor greater than one inferring to a higher volatility than market index Nifty and was highest for Bank of Baroda and lowest for Bank of Maharashtra. The value for total risk was highest for Andhra Bank \& Corporation Bank and lowest for Canra Bank. Upon deeper inspection, the proportion of systematic and unsystematic risk also varied as per different stocks; however, the former was lower in proportion compared to the latter in all cases.

The study has multiple implications for the government, central bank, policy makers, and portfolio or fund managers. The government, central bank, and other policy makers can introduce reforms to tackle issues discussed in the paper. Computation of beta factor and classification of systematic \& unsystematic risk can help individual investors as well as fund managers in building well-diversified portfolios. The reforms and performance indicators discussed can provide the basis for further industry analysis.

\section{REFERENCES}

1. Ranjan, R., \& Dhal, S. C. (2003). Non-performing loans and terms of credit of public sector banks in India: An empirical assessment. Reserve Bank of India Occasional Papers, 24(3).

2. Al-Tamimi, H., \& Al-Mazrooei, M. (2007). Deposit taking Micro financial institutions' Risk Management: A Comparison Study of UAE National and Foreign Deposit taking Micro financial institutions. The Journal of Risk Finance.

3. Bhide, M. G., Prasad, A., \& Ghosh, S. (2001). Emerging Challenges in Indian Banking. Retrieved from http:// mpra.ub.uni-muenchen.de/1711/ MPRA Paper No. 1711 (accessed 8 May, 2017).

4. Kamath, K. V., Kohli, S. S., Shenoy, P. S., Kumar R., Nayak, R. M., Kuppuswamy, P., T., \& Ravichandran, N. (2003). Indian banking sector: Challenges and opportunities. Vikalpa: The Journal for Decision Makers, 28(3), 83-100.

5. Mohan, R. (2005). Financial sector reforms in India: Policies and performance analysis. Economic and Political Weekly, 40(12), 1106-1121.

6. Dev, M. S. (2006). Financial inclusion: Issues and chal- lenges. Economic and Political Weekly, 41(41), 4310-4313.

7. Mohan, R. (2006). Economic growth, financial deepens- ing and financial inclusion. The Annual Bankers' Conference 2006, Hyderabad, 3 November 2006.

8. Golait, R. (2007). Current issues in agriculture credit in India: An assessment. Reserve Bank of India Occasional Papers, 28(1)

9. Raman, U. J. (2008). Operational risk management in Indian banks in the context of Basel II: A survey of the state of preparedness and challenges in developing the framework. Asia Pacific Journal of Finance and Banking Research, 2(2).

10. Ghosh, S. (2010). Credit growth, bank soundness and financial fragility evidence from Indian Banking Sector. South Asia Economic Journal, 11(1), 69-98.

11. Goyal, K. A., \& Joshi, V. (2011). Mergers in banking industry of India: Some emerging issues. Asian Journal of Business and Management Sciences, 1(2), 157-165.

12. Goyal, K. A., \& Joshi, V. (2012). Indian banking industry: Challenges and opportunities. Global Business and Management Research: An International Journal.

13. Singh, C., Mittal, A., Goenka, A., Goud, C. R. P., Ram, K., Suresh, R. V.,....., Kumar, U. (2014). Financial Inclusion in India: Select Issues. Working Paper 474.Retrieved from https://iimb.ac.in/research/sites/default/files/WP\%20No.\%20474.pdf

14. Singh, C. (2016). Challenges to financial inclusion. The Hindu Business Line. Retrieved from http://www.thehindubusinessline.com/opinion/jandhan-yoja-na-fraud-should-becurbed/article9169214.ece (accessed 12 June 2017).

15. Lakshmi, P. S. (2013). Volatility patterns in various sec- toral indices in Indian stock market. Global Journal of Management and Business Studies, 3(8), 879-886.

16. Rajamohan, S., \& Muthukamu, M. (2014). Bank nifty in- dex and other sectoral indices of NSE-A comparative study. PARIPEX-Indian Journal of Research, 3(4), 147-149.

17. William, A. J., \& Vimala, T. (2015). A study on equity share price volatility of selected private banks in national stock exchange. IMPACT: International Journal of Research in Applied, Natural and Social Sciences, 2(1), 88-95.

18. Shukrant, J. (2018). Identifying Financial \& Operating Issues and Measuring Systematic \& Unsystematic Risks: A Study of Indian Banking Sector. International Journal of Banking, Risk and Insurance, 6(2) 2018, 46-53 http://publishingindia.com/ijbri/

19. https://www1.nseindia.com/products/content/equities/i ndices/beta.html

20. Standards Australia and Standards New Zealand (2004), Australia/ New Zealand Standard Risk Management AS/NZS 4360:2004, Standards Australia, Sydney/Standards New Zealand, Auckland. Retrieved 30 March 2009, from www.saiglobal.com. 